\title{
Astragaloside IV reduces the expression level of P.glycoprotein in multidrug-resistant human hepatic cancer cell lines
}

\author{
PEI-PEI WANG ${ }^{1,3}$, DU-JUAN XU ${ }^{2,3}$, CAN HUANG $^{4}$, WEI-PING WANG $^{1}$ and WEN-KE XU ${ }^{1}$ \\ ${ }^{1}$ Department of Pharmacy, Yijishan Affiliated Hospital of Wannan Medical College, \\ Wuhu, Anhui 241001; ${ }^{2}$ Department of Pharmacy, The First Affiliated Hospital of Anhui Medical University; \\ ${ }^{3}$ Third-Grade Pharmaceutical Chemistry Laboratory of State Administration of Traditional Chinese Medicine, \\ Anhui Medical University, Hefei, Anhui 230022; ${ }^{4}$ Department of Pharmacy, \\ Anqing Shili Hospital, Anqing, Anhui 246003, P.R. China \\ Received July 5, 2013; Accepted February 24, 2014
}

DOI: $10.3892 / \mathrm{mmr} .2014 .2074$

\begin{abstract}
Astragaloside is a saponin widely used in traditional Chinese medicine and has been reported to be a potent multidrug resistance (MDR) reversal agent. The present study investigated the role of astragaloside IV (ASIV) in the regulation of $\mathrm{P}$-glycoprotein ( $\mathrm{P}$-gp, encoded by the $m d r l$ gene) and its effect on the reversal of MDR. The activity of ASIV was evaluated using human hepatic cancer cells Bel-7402 and the corresponding 5-fluorouracil (5-FU) resistant cells Bel-7402/FU. ASIV $(0.08 \mathrm{mg} / \mathrm{ml})$ potentiated the cytotoxicity of 5-FU which was demonstrated using the MTT assay on Bel-7402/FU cells. ASIV reduced the expression of P-gp as was revealed by immunocytochemistry. Accumulation and efflux studies with the P-gp substrate, rhodamine 123 (Rh123), demonstrated that ASIV inhibited P-gp-mediated drug efflux. Furthermore, it was demonstrated that ASIV enhanced the drug accumulation of 5-FU using a high performance liquid chromatography (HPLC) assay for drug resistant cells. Furthermore, ASIV may downregulate the expression of P-gp, which was examined using western blot analysis and polymerase chain reaction. In conclusion, the results of the present study indicated that ASIV reverses the drug resistance of Bel-7402/FU cells by downregulating the expression of $m d r l$. ASIV may represent a potent modulator of P-gp-mediated MDR in hepatic cancer therapy.
\end{abstract}

\section{Introduction}

Multidrug resistance (MDR) is considered a major cause of failure of anti-cancer chemotherapy. MDR is characterized by the simultaneous resistance to drugs that differ structurally and

Correspondence to: Dr Du-Juan Xu, Department of Pharmacy, The First Affiliated Hospital of Anhui Medical University, Anhui Medical University, 218 Jixi Road, Hefei, Anhui 230022, P.R. China. E-mail: xudujuan6365@yahoo.com.cn

Key words: astragaloside IV, P-glycoprotein, multidrug resistance, $\mathrm{ABCB} 1$ mechanistically (1). One of the major mechanisms of resistance in MDR mammalian cancer cells involves the increased expression of a $170 \mathrm{kDa}$ transmembrane protein, P-glycoprotein (P-gp). $\mathrm{P}$-gp, a member of the ATP binding cassette (ABC) transporter family, is encoded by $m d r l$ genes, also called ABCB1 and works in a similar manner to a pump to extrude anticancer drugs out of cells (2). P-gps expressed in the plasma membrane are mediators of MDR, actively effluxing a wide range of amphiphilic drugs irrespective of concentration gradient, thereby lowering intracellular concentrations to below therapeutic levels (3). The fact that P-gp is overexpressed in various cancer cells has prompted numerous research groups to search for effective inhibitors for this glycoprotein. Several compounds have been proposed as potential MDR modulators, including verapamil, PSC833 and XR9576 (4,5). Verapamil is one of the most extensively tested MDR modulators in the clinic and is used in conjunction with combination chemotherapy strategies. However, there has been limited success due to the cardiac toxicity associated with the high plasma levels required to effectively reverse MDR (6). To date, numerous natural compounds have been demonstrated to be capable of modulating P-gp transport, including rosmarinic acid, glaucine, gypenoside and oroxylin A (7-10).

Radix Astragali [the dried root of Astragalus membranaceus (Fisch.) Bunge and Astragalus mongholicus Bunge (Fabaceae)] is a nutraceutical commonly used in Traditional Chinese Medicine to treat a variety of diseases (11). It has been reported that Radix Astragali has immunostimulant, cardioprotective and antihyperglycemic effects (12-14). In pharmacopoeia and publications, astragaloside IV (ASIV; a $\beta$-D-glucopyranoside with the chemical name $(3 \beta, 6 \alpha, 16 \beta, 20 \mathrm{R}, 24 \mathrm{~S})-20,24$-epoxy-16 ,25-dihydroxy-3-( $\beta$-D-xylopyranosyloxy)-9,19-cyclolanostan6 -yl) (Fig. 1), is used as a marker for the active constituent in Radix Astragali.

The present study aimed to determine whether ASIV reversed the MDR of the Bel-7402/FU cell line by mechanisms involving the $\mathrm{P}-\mathrm{gp} / m d r l$ gene.

\section{Materials and methods}

Extraction and isolation of ASIV. ASIV preparation was performed according to a previously published method (15). 
Preparation of ASIV. ASIV was initially dissolved in $70 \%$ ethanol and was subsequently dissolved in phosphate buffered saline (PBS) to form a stock solution with a concentration of $4 \mathrm{mg} / \mathrm{ml}$. When the stock solution was used it was diluted to the required concentration with Dulbecco's modified Eagle medium (DMEM; Gibco, Carlsbad, CA, USA), with the proportion of alcohol in the final concentration $<1 \%$.

Cell culture. The drug-sensitive human hepatic cancer cell line Bel-7402 and the corresponding 5-fluorouracil (5-FU)-resistant Bel-7402/FU cell line were purchased from Keygen Biotech (Nanjing, China). All cells were grown in DMEM (Gibco) supplemented with $10 \%$ fetal bovine serum (Gibco) in a $\mathrm{CO}_{2}$ incubator. Bel-7402/FU cells were cultured in the previously mentioned medium with addition of $20 \mu \mathrm{g} / \mathrm{ml} 5-\mathrm{FU}$ (Tianjin Taihe Pharmaceutical Co., Ltd., Tianjin, China).

Determination of MDR. Bel-7402 cells and Bel-7402/FU cells were seeded into 96 -well plates at $1 \times 10^{4}$ cells per well. Following $12 \mathrm{~h}$ of incubation, cells were treated with various concentrations of 5-FU, mitomycin (Kyowa Hakko Kirin Co., Ltd., Fuji Plant, Shizuoka, Japan) and adriamycin (Actavis Italy S.P.A., Nerviano, Italy) at $0.2,1,5,25$ or $125 \mu \mathrm{g} / \mathrm{ml}$ for $48 \mathrm{~h}$. Drug sensitivity was determined by MTT assay according to the manufacturer's instructions (Sigma-Aldrich, St. Louis, MO, USA). Data were obtained by analyzing the absorption at $550 \mathrm{~nm}$ with an automated microplate reader (680; Bio-Rad, Hercules, CA, USA). The $\mathrm{IC}_{50}$-values represent the concentrations of the assayed enzymes required to inhibit cell proliferation by $50 \%$ and were calculated by using SPSS 13.0 (IBM, Armonk, NY, USA). All reported values are the means of at least three independent experiments. The resistance fold ( $\mathrm{RF}$ ) was calculated by dividing the $\mathrm{IC}_{50}$ of resistant cells by the $\mathrm{IC}_{50}$ of sensitive cells.

Determination of cytotoxicity and MDR reversal fold. The in vitro cytotoxicity of ASIV was measured by the MTT assay. Bel-7402 and Bel-7402/FU cells were treated with 0.04, 0.08, $0.16,0.32$ or $0.64 \mathrm{mg} / \mathrm{ml} \mathrm{ASIV}$ for $48 \mathrm{~h}$. The inhibition rate of ASIV on cells was determined using the same MTT assay as described previously.

Bel-7402/FU cells were seeded at $1 \times 10^{4}$ cells/well and treated with 5 -FU $(0.025 \mathrm{mg} / \mathrm{ml})$ alone, or in combination with ASIV $(0.04$ or $0.08 \mathrm{mg} / \mathrm{ml})$ or $0.001 \mathrm{mg} / \mathrm{ml}(+)$-verapamil (purity >99\%; Sigma-Aldrich) with 5-FU. Subsequently, the cells were exposed to 5-FU, ASIV or verapamil continuously for $48 \mathrm{~h}$ and the cytotoxicity was assessed by MTT assay. The relative reversal fold (RRF) was calculated by dividing the inhibition rate of Bel-7402/FU cells treated with 5-FU and a modulator (ASIV or verapamil) by the inhibition rate of Bel-7402/FU cells treated with 5-FU.

Immunocytochemistry. The intracellular location and relative expression of P-gp was observed by immunocytochemistry. The cells $\left(5 \times 10^{4} / \mathrm{ml}\right)$ were exposed to 0.08 or $0.16 \mathrm{mg} / \mathrm{ml}$ ASIV or $0.001 \mathrm{mg} / \mathrm{ml}$ verapamil for $24 \mathrm{~h}$. P-gp was detected using rabbit anti-P-gp monoclonal immunoglobulin $\mathrm{G}$ ( $\mathrm{IgG}$; Wuhan Boshide Biological Engineering Co., Ltd., Wuhan, Hubei, China) in a 1:200 dilution at $4^{\circ} \mathrm{C}$ overnight. Subsequently, cells were rinsed three times with phosphate-buffered saline (PBS),

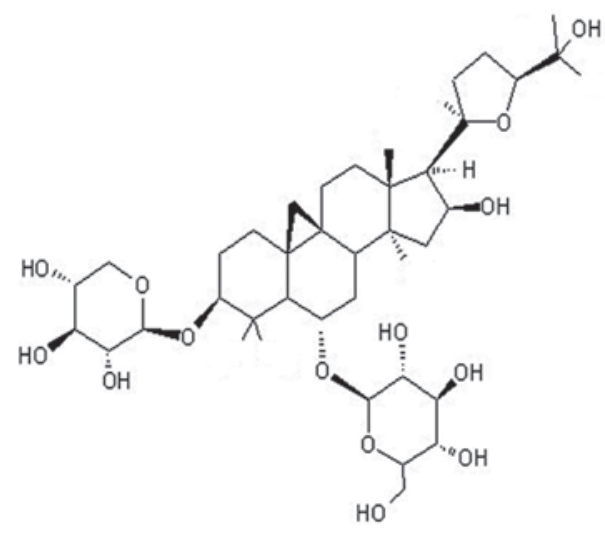

Figure 1. Chemical structure of astragaloside IV.

Table I. Sensitivity of Bel-7402 and Bel-7402/FU cells treated with chemotherapeutic drugs.

\begin{tabular}{llll}
\hline & \multicolumn{2}{c}{$\mathrm{IC}_{50}(\mu \mathrm{g} / \mathrm{ml})$} & \\
\cline { 2 - 3 } Drugs & Bel-7402/FU & Bel-7402 & RF of MDR \\
\hline 5-Fluorouracil & $63.35 \pm 1.0$ & $3.226 \pm 0.3^{\mathrm{a}}$ & 19.64 \\
Adriamycin & $3.259 \pm 0.4$ & $1.643 \pm 0.5$ & 1.98 \\
Mitomycin & $4.428 \pm 0.6$ & $2.308 \pm 0.7$ & 1.92 \\
\hline
\end{tabular}

$\mathrm{IC}_{50}$ is defined as the concentration required to reduce cell proliferation and viability by $50 \%$. All data represent the mean \pm standard deviation for at least three independent experiments. ${ }^{a} \mathrm{P}<0.01$ compared with Bel-7402/FU cells. RF, resistance fold; MDR, multidrug resistance.

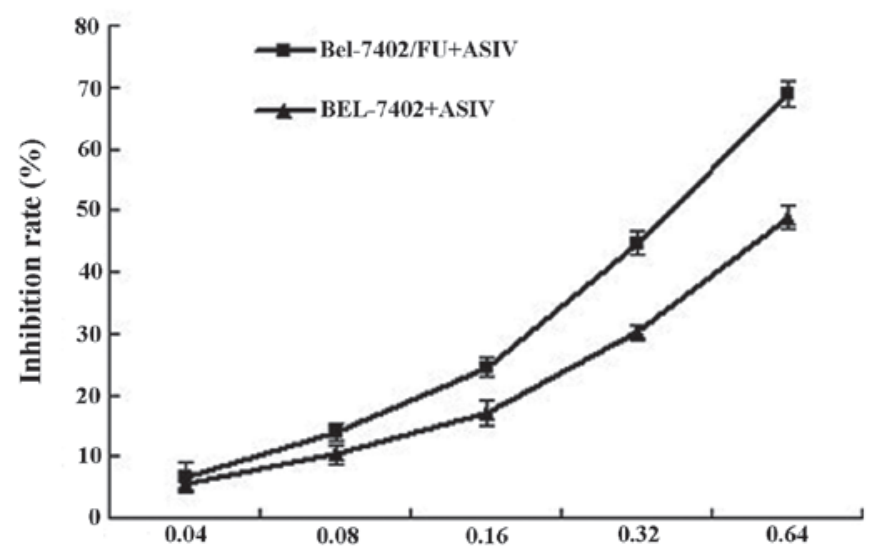

Figure 2. Cytotoxicity of Bel-7402 and Bel-7402/FU cells induced by ASIV. Following $48 \mathrm{~h}$ of treatment with ASIV, the inhibition rate of cell viability was assessed using the MTT assay. ASIV, astragaloside IV.

and incubated with horseradish peroxidase-conjugated goat anti-rabbit IgG $(\mathrm{H}+\mathrm{L}$; Wuhan Boshide Biological Engineering Co., Ltd.) at 1:200 dilution. Cells were observed using fluorescence microscopy (BX51; Olympus, Center Valley, PA, USA).

Flow cytometric analysis of $P$-gp function. The cells $\left(5 \times 10^{5} / \mathrm{ml}\right)$ were incubated with or without ASIV (0.08 or $0.16 \mathrm{mg} / \mathrm{ml})$ or 
A

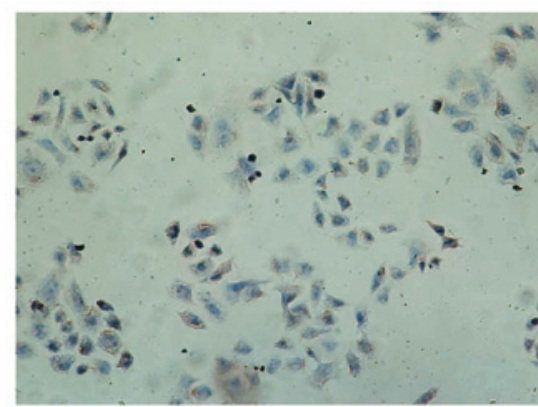

Be1-7402 ce1ls

C

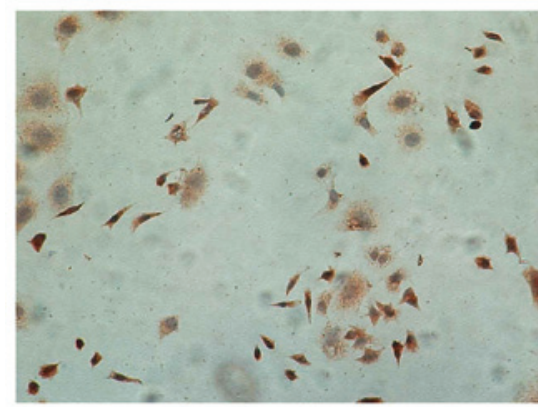

ASIV $0.08 \mathrm{mg} / \mathrm{ml}$

E

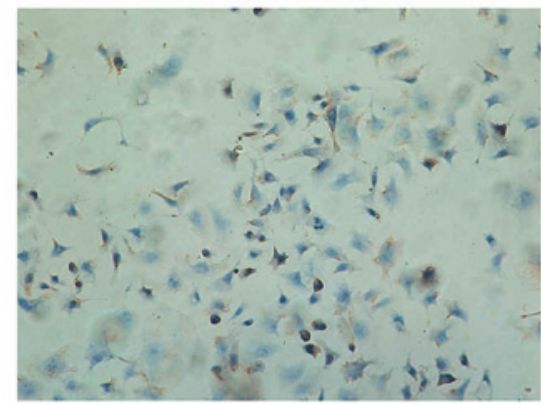

verapamil $0.001 \mathrm{mg} / \mathrm{ml}$

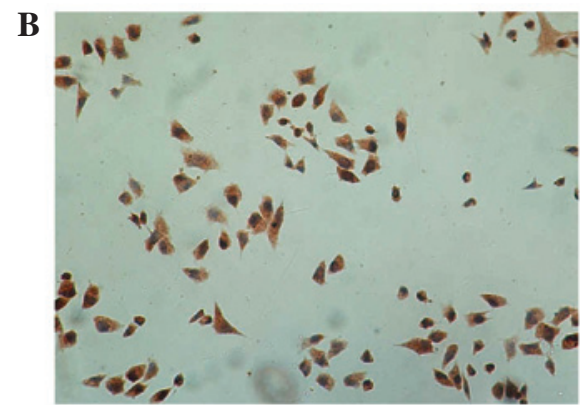

Be1-7402/FU cells

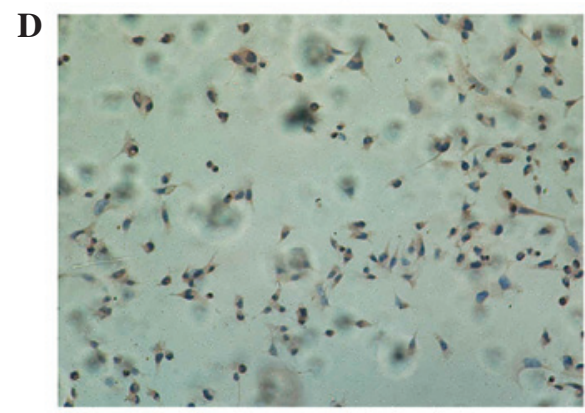

ASIV $0.16 \mathrm{mg} / \mathrm{ml}$

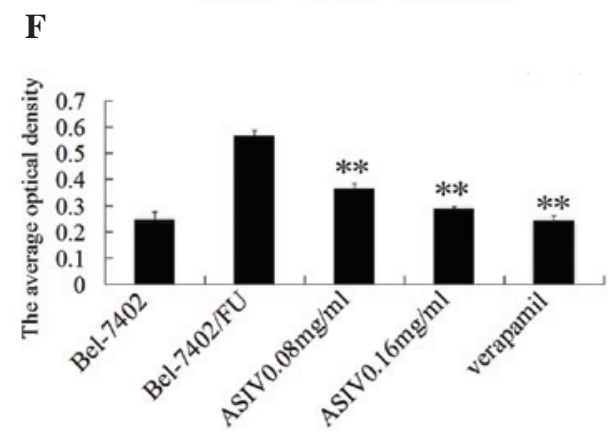

Figure 3. Effect of ASIV on P-glycoprotein by immunocytochemistry assay. Cells were viewed under a fluorescence microscope, magnification, x400. (A) Bel-7402 cells. (B) Bel-7402/FU cells. (C) Bel-7402/FU cells were treated with $0.08 \mathrm{mg} / \mathrm{ml} \mathrm{ASIV.} \mathrm{(D)} \mathrm{Bel-7402/FU} \mathrm{cells} \mathrm{were} \mathrm{treated} \mathrm{with} \mathrm{0.16} \mathrm{mg/ml} \mathrm{ASIV.}$ (E) Bel-7402/FU cells were treated with $0.001 \mathrm{mg} / \mathrm{ml}$ verapamil. Every image was captured by fluorescence microscopy (magnification, $\mathrm{x} 400$ ) from at least five fields of view. (F) The values of the average optical density were determined using IMAGE-PRO plus image analysis software. Data are the mean \pm standard deviation of three independent experiments. ${ }^{* *} \mathrm{P}<0.01$, modulator- treated Bel-7402/FU cells vs. untreated Bel-7402/FU cells. ASIV, astragaloside IV.

verapamil $(0.001 \mathrm{mg} / \mathrm{ml})$ for $24 \mathrm{~h}$ at $37^{\circ} \mathrm{C}$. A total of $10^{6}$ cells were incubated with $5 \mu \mathrm{g} / \mathrm{ml}$ rhodamine 123 (Rh123) (Sigma-Aldrich) for $1 \mathrm{~h}$ at $37^{\circ} \mathrm{C}$, washed twice with cold PBS and incubated for $30 \mathrm{~min}$ in dye-free medium. Cell fluorescence was evaluated using a flow cytometer (FC500; Beckman Coulter, Miami, FL, USA) at an excitation wavelength of $488 \mathrm{~nm}$ and emission wavelength of $525 \mathrm{~nm}$.

Determination of intracellular drug concentration. Bel-7402/FU cells $\left(5 \times 10^{5} / \mathrm{ml}\right)$ were exposed to $0.025 \mathrm{mg} / \mathrm{ml}$ 5 -FU in the presence or absence, of $0.08 \mathrm{mg} / \mathrm{ml} \mathrm{ASIV} \mathrm{or}$ $0.001 \mathrm{mg} / \mathrm{ml}$ verapamil for $24 \mathrm{~h}$ at $37^{\circ} \mathrm{C}$. Following trypsinization, the cells were extracted with $500 \mu \mathrm{l}$ of methanol by ultrasonication and centrifuged at $12,000 \mathrm{x}$ g for $30 \mathrm{~min}$ at $4^{\circ} \mathrm{C}$. The supernatant was filtered and dried with nitrogen gas. Subsequently, the mobile phase was added to achieve a metered volume of $0.5 \mathrm{ml}$ for the quantitative analysis. Analysis was performed using the Agilent 1100 high performance liquid chromatography (HPLC) system (Agilent Technologies, Santa
Clara, CA, USA) comprised of a quaternary pump, an autosampler and a UV detector. A C18 column $(250 \mathrm{x} 4.6 \mathrm{~mm}, 5 \mu \mathrm{m}$, Diamonsil; Dikma, Lake Forest, CA, USA) was used for the separation. The flow rate was $1 \mathrm{ml} / \mathrm{min}$ with methanol:water $(10: 90, \mathrm{v} / \mathrm{v})$ as the mobile phase. Peak areas were determined at $265 \mathrm{~nm}$ for $5-\mathrm{FU}$.

Determination of mdrl $\mathrm{mRNA}$ by quantitative polymerase chain reaction ( $q P C R$ ). Bel-7402 cells and Bel-7402 cells $\left(5 \times 10^{5} / \mathrm{ml}\right)$ were untreated or treated with $0.08 \mathrm{mg} / \mathrm{ml}$ or $0.16 \mathrm{mg} / \mathrm{ml} \mathrm{ASIV}$ or $0.001 \mathrm{mg} / \mathrm{ml}$ verapamil for $24 \mathrm{~h}$. Total RNA was isolated using TRIzol ${ }^{\circledR}$ reagent (Invitrogen Life Technologies, Carlsbad, CA, USA) and qPCR was performed. The primers were as follows: $m d r l$ forward, 5'-AAAGTCGGAGTATCTTCTTCCAA-3' and reverse, 5'-CCAATTTGAATAGCGAAACATTGA-3'); GAPDH forward, 5'-GTGAAGGTCGGTGTCAACGGATTT-3' and reverse, 5'-CACAGTCTTCTGAGTGGCAGTGAT-3'). PCR conditions were $60 \mathrm{sec}$ at $94^{\circ} \mathrm{C}$, followed by 35 cycles 
Table II. Reversal effects of ASIV on Bel-7402/FU cells.

\begin{tabular}{lccc}
\hline Drugs & Concentrations $(\mathrm{mg} / \mathrm{ml})$ & Inhibition rates $(\%)$ & RRF \\
\hline 5-Fluorouracil & 0.025 & $0.129 \pm 0.04$ & - \\
ASIV + 5-fluorouracil & $0.04+0.025$ & $0.209 \pm 0.02$ & $1.70 \pm 0.43$ \\
& $0.08+0.025$ & $0.230 \pm 0.03^{\mathrm{b}}$ & $1.86 \pm 0.41$ \\
Verapamil + 5-fluorouracil & $0.001+0.025$ & $0.267 \pm 0.03^{\mathrm{a}}$ & $2.16 \pm 0.48$
\end{tabular}

RRF was calculated as the ratio of the inhibition rate of Bel-7402/FU cells treated with a modulator and 5-fluorouracil to the inhibition rate of Bel-7402/FU cells treated with 5-fluorouracil alone. Data are presented as the mean \pm standard deviation of three independent experiments compared with Bel-7402/FU cells treated with 5-fluorouracil alone, ${ }^{\mathrm{a}} \mathrm{P}<0.01$; ${ }^{\mathrm{b}} \mathrm{P}<0.05$. ASIV, astragaloside IV; RRF, relative reversal fold.

A

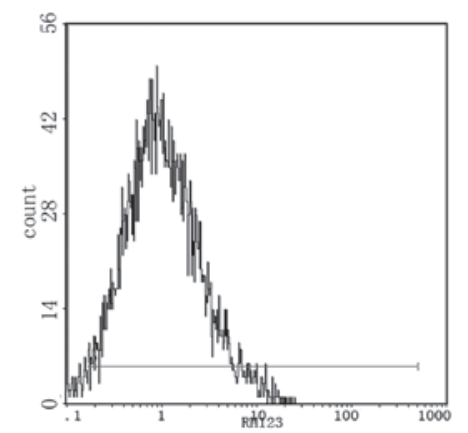

C

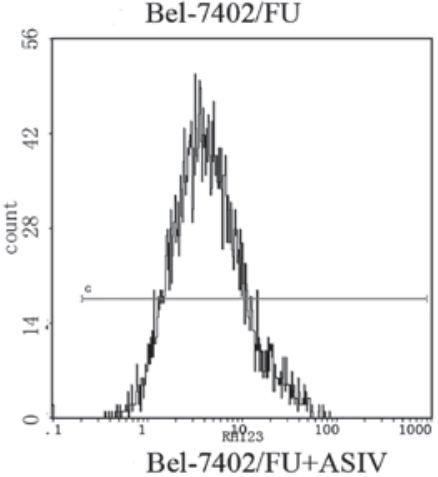

$\mathbf{E}$
B

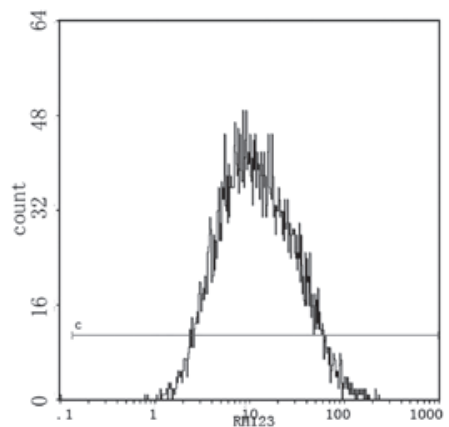

D

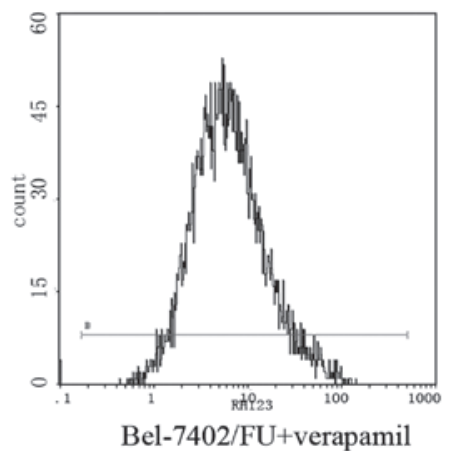

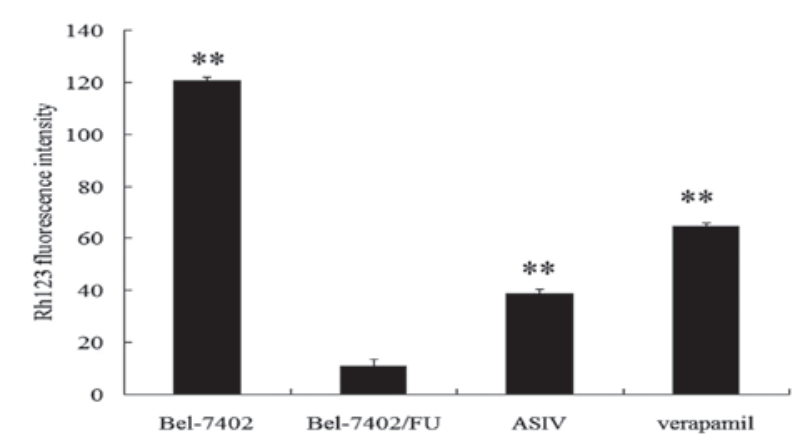

Figure 4. Accumulation and retention of Rh123 in Bel-7402 and Bel-7402/FU cells. The cells were incubated with Rh123 for 60 min prior to being measured by flow cytometry. The intracellular Rh123 concentration was determined. (A) Bel-7402/FU cells; (B) Bel-7402 cells; (C) Bel-7402/FU cells were treated with $0.08 \mathrm{mg} / \mathrm{ml}$ ASIV; (D) Bel-7402/FU cells were treated with $0.001 \mathrm{mg} / \mathrm{ml}$ verapamil. (E) Rh123 fluorescence intensity. Data are the means \pm standard deviation of three independent experiments. ${ }^{*} \mathrm{P}<0.05,{ }^{* *} \mathrm{P}<0.01$, compared with the Bel-7402/FU cells control group. ASIV, astragaloside IV; Rh123, rhodamine 123.

of denaturation at $94^{\circ} \mathrm{C}$ for $60 \mathrm{sec}$; annealing for $40 \mathrm{sec}$ at $56^{\circ} \mathrm{C}$; elongation for $60 \mathrm{sec}$ at $72^{\circ} \mathrm{C}$, followed by $10 \mathrm{~min}$ at $72^{\circ} \mathrm{C}$. There were 35 cycles for $m d r l$ and 30 for GAPDH. The total amplification product was subjected to $1.5 \%$ agarose gel electrophoresis.
Western blot analysis. Bel-7402 and Bel-7402/FU cells $\left(5 \times 10^{5} / \mathrm{ml}\right)$ were treated with $0.08 \mathrm{mg} / \mathrm{ml}$ or $0.16 \mathrm{mg} / \mathrm{ml} \mathrm{ASIV}$ or $0.001 \mathrm{mg} / \mathrm{ml}$ verapamil. Cells were lysed in a radioimmunoprecipitation assay buffer (Sigma-Aldrich). Cell lysates were boiled at $100^{\circ} \mathrm{C}$ and cytosolic proteins were separated 


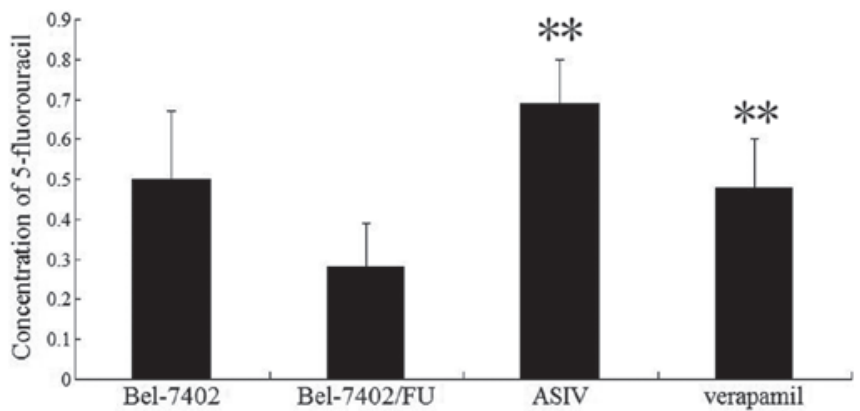

Figure 5. High performance liquid chromatography analysis of the intracellular concentration of 5-FU. The concentration of 5-FU was calculated as the percentage of the total area under the curve for each sample. Intracellular concentrations of 5-FU in untreated control cells were $0.50 \pm 0.17$ and $0.28 \pm 0.11$ for Bel-7402 and Bel-7402/FU cells, respectively. Data represent the mean \pm standard deviation of three independent experiments. ${ }^{* *} \mathrm{P}<0.01$, compared with Bel-7402/FU cells treated with $0.025 \mathrm{mg} / \mathrm{ml} 5$-FU. ASIV, astragalocide IV; 5-FU, 5-fluorouracil.
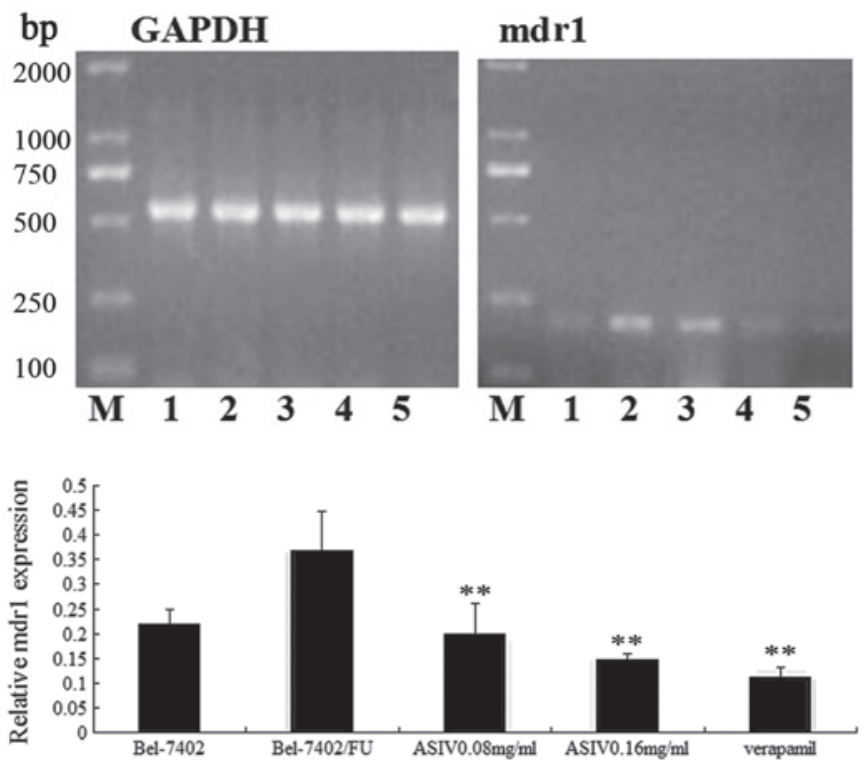

Figure 6. Effect of ASIV on $m d r l$ mRNA levels assessed by PCR. The level of GAPDH (PCR product $558 \mathrm{bp}$ ) and $m d r l$ gene (PCR product $201 \mathrm{bp}$ ) were determined. M, Marker DL2000; 1, Bel-7402 cells control 2, Bel-7402/FU cells control; 3, Bel-7402/FU cells treated with $0.08 \mathrm{mg} / \mathrm{ml}$ ASIV; 4, Bel-7402/FU cells treated with $0.16 \mathrm{mg} / \mathrm{ml} \mathrm{ASIV;} \mathrm{5,} \mathrm{Bel-7402/FU}$ cells treated with $0.001 \mathrm{mg} / \mathrm{ml}$ verapamil. Relative $m d r l$ mRNA levels were calculated by the ratio of $m d r l$ densitometric value to the GAPDH densitometric value. Values are presented as the mean \pm standard deviation of triplicate experiments. ${ }^{* *} \mathrm{P}<0.01$, modulator-treated Bel-7402/FU cells vs untreated Bel-7402/FU cells. ASIV, astragalocide IV; PCR, polymerase chain reaction; mdr, multidrug resistance.

using 10\% SDS-PAGE, transferred onto polyvinylidene fluoride (PVDF) membranes, probed with appropriate antibodies, including goat anti human P-gp monoclonal IgG (Santa Cruz Biotechnology, Inc., Santa Cruz, CA, USA) and horseradish peroxidase-conjugated rabbit anti goat IgG (Santa Cruz Biotechnology, Inc.), and visualized with enhanced chemiluminescence (ECL; Thermo Scientific, Wilmington, DE, USA).

Statistical analysis. The results are presented as the mean \pm standard deviation $(n \geq 3)$. Statistical analysis was
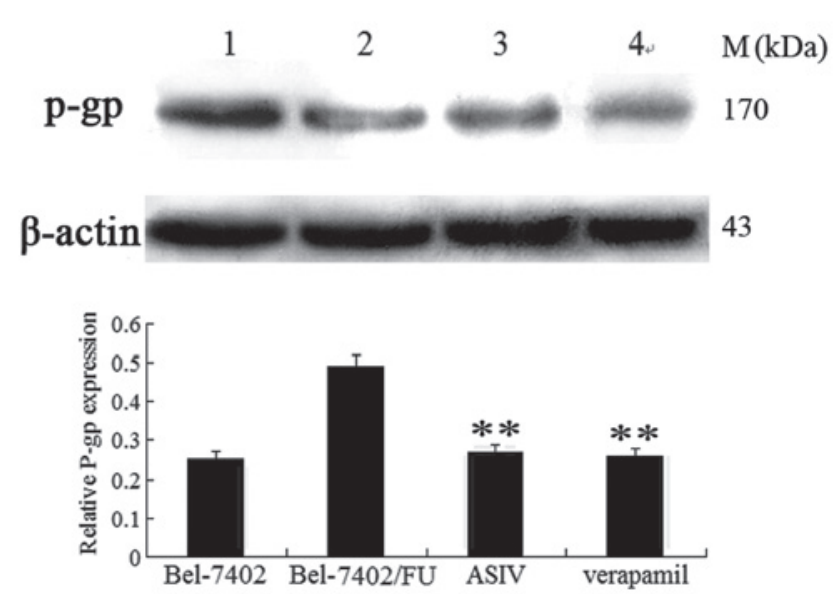

Figure 7. Effect of ASIV on P-gp expression by western blot analysis. 1, Bel-7402/FU cells control; 2, Bel-7402 cells control; 3, Bel-7402/FU cells treated with $0.08 \mathrm{mg} / \mathrm{ml}$ ASIV; 4 , Bel-7402/FU cells treated with $0.001 \mathrm{mg} / \mathrm{ml}$ verapamil. The intensities of the P-gp bands were normalized to $\beta$-actin. The ratio of $\mathrm{P}$-gp to $\beta$-actin was calculated and expressed relative to that in Bel-7402 and Bel-7402/FU cells. Data are presented as the mean \pm standard deviation of three experiments. ${ }^{* *} \mathrm{P}<0.01$, modulator-treated Bel-7402/FU cells vs. untreated Bel-7402/FU cells. P-gp, P-glycoprotein; ASIV, astragalocide IV.

performed with the Student's t-test. $\mathrm{P}<0.05$ was considered to indicate a statistically significant difference.

\section{Results}

Determination of MDR. The MTT assay demonstrated that Bel-7402/FU cells were resistant not only to 5-FU but also to adriamycin and mitomycin. Bel-7402/5-FU cells were 19.64-fold more resistant than the control Bel-7402 cells to 5-FU (Table I).

Cytotoxicity assay of ASIV. The intrinsic toxicity of ASIV was evaluated in order to ascertain the ability of the modulator to reverse the resistance at nontoxic concentrations. ASIV inhibited the proliferation of Bel-7402 and Bel-7402/FU cells in a dose-dependent manner (Fig. 2). As determined by the dose-effect curve, 0.04 and $0.08 \mathrm{mg} / \mathrm{ml}$ of ASIV were not cytotoxic (inhibition rate $<5 \%$ ). Thus, the concentration of 0.04 or $0.08 \mathrm{mg} / \mathrm{ml}$ ASIV was used as the dose for the reversal effect of MDR.

ASIV reverses the resistance of Bel-7402/FU cells to 5-FU. The in vitro MDR reversing activity of ASIV was studied by determining the cytotoxicity of $5-\mathrm{FU}$ in Bel-7402/FU cells (Table II). In the presence of $0.08 \mathrm{mg} / \mathrm{ml} \mathrm{ASIV,} \mathrm{the}$ Bel-7402/FU cells exhibited a significantly increased sensitivity to 5-FU. The potency of ASIV was comparable with that of verapamil. The results demonstrated that ASIV was able to reverse MDR in vitro.

ASIV decreases P-gp expression. In order to observe the intracellular location of P-gp and assess the P-gp levels, immuncytochemistry was performed (Fig. 3). Using fluorescence microscopy, the positive response of P-gp was indicated by brown-yellow staining, mainly located in the cytoplasm 
and cytomembrane, demonstrating a uniform fine granular distribution. As the expression of the Bel-7402/FU group increased, the color darkened. Following the treatment of Bel-7402/FU cells with 0.08 or $0.16 \mathrm{mg} / \mathrm{ml}$ ASIV, P-gp expression decreased, the color became lighter and the number of brown-yellow granules in the cytoplasm reduced significantly.

ASIV decreases the transport activity of $P$ - $g p$. The ability of ASIV to inhibit P-gp-mediated transport was investigated using the P-gp substrate rhodamine 123 (Rh123). Fig. 4 illustrates that Rh123 accumulation in Bel-7405/FU cells was markedly lower than that found in Bel-7402 cells. Bel-7402/FU cells preincubated with ASIV for $48 \mathrm{~h}$ exhibited an increase in the intracellular accumulation of fluorescent Rh123.

ASIV enhances the intracellular accumulation of 5-FU. Intracellular 5-FU accumulation was determined by incubation of Bel-7402/FU cells with $5-\mathrm{FU}(0.025 \mathrm{mg} / \mathrm{ml})$ in the presence or absence of $(0.08 \mathrm{mg} / \mathrm{ml})$ ASIV by HPLC. Fig. 5 demonstrates that ASIV increased the intracellular accumulation of 5-FU in Bel-7402/FU cells.

ASIV downregulates mdrl expression. Whether ASIV affected $m d r l$ mRNA and P-gp expression was examined using qPCR and western blot analysis. As shown in Fig. 6, mdrl gene expression was markedly increased in Bel-7402/FU cells compared with Bel-7402 cells. The levels of $m d r l$ mRNA were decreased by $0.08 \mathrm{mg} / \mathrm{ml} \mathrm{ASIV} \mathrm{and}$ completely deregulated by $0.16 \mathrm{mg} / \mathrm{ml}$ ASIV. As shown in Fig. 7, $0.08 \mathrm{mg} / \mathrm{ml}$ ASIV decreased the P-gp levels in Bel-7402/FU cells.

\section{Discussion}

Intrinsic and acquired resistance of malignant cells to cytotoxic agents is a major cause of treatment failure during chemotherapy (16). One of the well-established mechanisms of resistance is the MDR process, due to increased ABC transporter expression (17). Inhibition of drug transporters and modulating MDR are among the most important strategies in the field of cancer chemotherapy.

Previous studies have reported that astragaloside II (ASII) may be capable of reversing hepatoma MDR in vitro by downregulating the expression of the $m d r l$ gene and P-gp. However, ASII may also inhibit the mitogen-activated protein kinase (MAPK) signal transduction pathway (15). ASIV has been proven to be a novel anti-inflammatory agent and has been suggested as a potential agent for the treatment of cardiovascular diseases $(18,19)$. However, few studies have reported on the effects of ASIV on the reversal of MDR and its molecular mechanisms. In the present study, the in vitro potency of ASIV was evaluated with several assays using human hepatic cancer Bel-7402 and Bel-7402/FU cells. Cytotoxicity assays of several anticancer drugs (5-FU, adriamycin and mitomycin) demonstrated that Bel-7402/FU cells were 19.64-fold more resistant to 5-FU than Bel-7402 cells. In order to investigate the reversal effect of ASIV on drug resistant cells, ASIV was administered to cells at the nontoxic concentrations of 0.04 or $0.08 \mathrm{mg} / \mathrm{ml}$, which increased the sensitivity of Bel-7402/FU cells to 5-FU by 1.87-fold. Therefore, ASIV partially reversed the MDR of Bel-7402/FU cells

$\mathrm{P}$-gp is expressed in a cell- and tissue-specific manner, with high levels detectable in the kidney, liver and intestine (20). The immuncytochemistry assay demonstrated that ASIV significantly inhibited P-gp expression.

The overexpression of P-gp on the surface of tumor cells leads to MDR. This protein acts as an energy-dependent drug efflux pump, reducing the intracellular concentration of structurally unrelated drugs. In the study of accumulation and efflux, sensitive hepatic cancer Bel-7402 cells acted as a negative control and accumulated the most Rh123 compared with Bel-7402/FU cells which accumulated the least (21). However, Bel-7402/FU cells treated with ASIV accumulated more Rh123 than untreated cells. Further confirmation of ASIV inhibiting P-gp-mediated drug efflux was provided by the fact that the modulator increased the intracellular accumulation of 5-FU in Bel-7402/FU cells, according to HPLC analysis. These studies indicated that the reversal of MDR by ASIV was through the enhancement of drug uptake and the inhibition of P-gp mediated drug efflux. Similarly, the reversal of P-gp-mediated MDR with milbemycins correlated with an increase in the accumulation of adriamycin and Rh123 via the inhibition of P-gp efflux in MCF-7/adr cells (22).

The inhibition of P-gp function or inhibition of its expression was able to prevent the P-gp-mediated MDR phenotype and improve the effectiveness of chemotherapy (23).

qPCR and western blot analyses were performed in order to determine the interaction of ASIV with the $m d r l$ gene and P-gp. The qPCR assay revealed that ASIV downregulated $m d r 1$ mRNA expression in Bel-7402/FU cells. Furthermore, western blot analysis revealed that ASIV downregulated P-gp expression in Bel-7402/FU cells. Thus, the downregulation of the $m d r l$ gene and P-gp expression by ASIV may be involved in the reversal of MDR.

The MAPK pathway is an important signal transduction pathway activated by various stimuli. Previous reports have demonstrated that modulators of the MAPK pathway may affect the drug transport activity of P-gp in certain multidrug-resistant cell lines $(24,25)$. Adenovirus-mediated enhancement of c-Jun $\mathrm{NH}_{2}$-terminal kinase (JNK) reduces the levels of P-gp and reverses P-gp-mediated MDR in human gastric carcinoma resistant cell lines (26). BIRB796, an active inhibitor of p38 MAPK, reverses P-gp-mediated MDR by directly inhibiting its transport function (27). Previous studies have reported that ASII suppressed the phosphorylation of extracellular signal regulated kinase1/2, p38 and the c-Jun $\mathrm{NH}_{2}$-terminal kinase. Whether ASIV downregulates P-gp expression via the MAPK pathway requires to be elucidated by future studies.

In conclusion, ASIV has the potential to be used as a P-gp-mediated MDR reversal agent and may be a potential adjunctive agent for human hepatic cancer chemotherapy.

\section{Acknowledgements}

The present study was supported by the Anhui Provincial Natural Science Foundation (no. 11040606M222) and the Key Research Project Cultivated Fund of Wannan Medical College (no. WK2013ZF05). 


\section{References}

1. Gottesman MM, Fojo T and Bates SE: Multidrug resistance in cancer: role of ATP-dependent transporters. Nat Rev Cancer 2: 48-58, 2002

2. Solazzo M, Fantappiè O, Lasagna N, Sassoli C, Nosi D and Mazzanti R: P-gp localization in mitochondria and its functional characterization in multiple drug-resistant cell lines. Exp Cell Res 312: 4070-4078, 2006.

3. Pluchino KM, Hall MD, Goldsborough AS, Callaghan R and Gottesman MM: Collateral sensitivity as a strategy against cancer multidrug resistance. Drug Resist Updat 15: 98-105, 2012.

4. Bark $\mathrm{H}$ and Choi $\mathrm{CH}$ : PSC 833 , cyclosporine analogue, downregulates $M D R 1$ expression by activating JNK/c-Jun/AP-1 and suppressing NF-kappaB. Cancer Chemother Pharmacol 65: 1131-1136, 2010.

5. Mistry P, Stewart AJ, Dangerfield $\mathrm{W}$, et al: In vitro and in vivo reversal of P-glycoprotein-mediated multidrug resistance by a novel potent modulator, XR9576. Cancer Res 61: 749-758, 2001.

6. Dalton WS, Grogan TM, Meltzer PS, et al: Drug-resistance in multiple myeloma and non-Hodgkin's lymphoma: detection of P-glycoprotein and potential circumvention by addition of verapamil to chemotherapy. J Clin Oncol 7: 415-424, 1989.

7. Li FR, Fu YY, Jiang DH, et al: Reversal effect of rosmarinic acid on multidrug resistance in SGC7901/Adr cell. J Asian Nat Prod Res 15: 276-285, 2013.

8. Lei Y,Tan J,WinkM,MaY,LiNand Su G: Anisoquinoline alkaloid from the Chinese herbal plant Corydalis yanhusuo W.T. Wang inhibits P-glycoprotein and multidrug resistance-associate protein 1. Food Chem 136: 1117-1121, 2013.

9. Zhu H,Liu Z, Tang L, et al: Reversal of P-gp and MRP1-mediated multidrug resistance by $\mathrm{H6}$, a gypenoside aglycon from Gynostemma pentaphyllum, in vincristine-resistance human oral cancer(KB/VCR) cell. Eur J Pharmacol 696: 43-53, 2012.

10. Zhu L, Zhao L, Wang H, et al: Oroxylin A reverse P-glycoproteinmediated multidrug resistance of MCF7/ADR cells by G2/M arrest. Toxicol Lett 23: 107-115, 2013.

11. Song JZ, Yiu HH, Qiao CF, Han QB and Xu Hx: Chemical comparison and classification of Radix Astragali by determination of isoflavonoids and astragalosides. J Pharm Biomed Anal 47: 399-406, 2008.

12. Zhao LH, Ma ZX, Zhu J, Yu XH and Wang DP: Characterizaion of polysaccharide from Astragalus radix as the macrophage stimulator. Cell Immunol 271: 329-334, 2011.

13. Wang X, Xu X, Tao W, Li Y, Wang Y and Yang L: A systems biology approach to uncovering pharmacological synergy in herbal medicines with applications to cardiovascular disease. Evid Based Complement Alternat Med 2012: 519031, 2012.
14. Yuan YM, Gao JW, Shi Z, et al: Herb-drug pharmacokinetic interaction between radix astragali and pioglitazone in rats. J Ethnopharmacol 144: 300-304, 2012.

15. Huang C, Xu D, Xia Q, Wang P, Rong C and Su Y: Reversal of P-glycoprotein-mediated multidrug resistance of human hepatic cancer cells by Astragaloside II. J Pharm Pharmacol 64: 1741-1750, 2012.

16. Yu M, Ocana A and Tannock IF: Reversal of ATP-binding cassette drug transporter activity to modulate chemoresistance: why has it failed to provide clinical benefit? Cancer Metastasis Rev 32: 211-227, 2013

17. Leonard GD, Fojo T and Bates SE: The role of ABC transporters in clinical practice. Oncologist 8: 411-424, 2003.

18. Gui D, Huang J, Guo Y, et al: Astragaloside IV ameliorates renal injury in streptozotocin-induced diabetic rats through inhibiting NF-kappaB-mediated inflammatory genes expression. Cytokine 61: 970-977, 2013.

19. Zhao J, Yang P, Li F, et al: Therapeutic effects of astragaloside IV on myocardial injuries: multi-target identification and network analysis. PLoS One 7: e44938, 2012.

20. Thiebaut F, Tsururo T, Hamada H, Gottesman MM, Pastan I and Willingharm MC: Cellular localization of the multidrugresistance gene product P-glycoprotein in normal human tissues. Proc Natl Acad Sci USA 84: 7735-7738, 1987.

21. Eichhorn T and Efferth T: P-glycoprotein and its inhibition in tumors by phytochemical derived from Chinese herbs. J Ethnopharmacol 141: 557-570, 2012.

22. Gao A, Liang H, Wang XJ, et al: Reversal effects of two new milbemycin compounds on multidrug resistance in MCF-7/adr cells in vitro. Eur J Pharmacol 659: 108-113, 2011.

23. Hait WN and Yang JM: Clinical management of recurrent breast cancer: development of multidrug resistance (MDR) and strategies to circumvent it. Semin Oncol 32:S16-S21, 2005.

24. Huang C, Xu D, Xia Q, Wang P, Rong C and Su Y: Reversal of P-glycoprotein-mediated multidrug resistance of human hepatic cancer cells by Astragaloside II. J Pharm Pharmacol 64: 1741-1750, 2012.

25. Shinoda C, Maruyama M, Fujishita T, et al: Doxorubicin induces expression of multidrug resistance-associated protein 1 in human small cell lung cancer cell lines by the c-jun N-terminal kinase pathway. Int J Cancer 117: 21-31, 2005.

26. Zhou J, Liu M, Aneja R, Chandra R, Lage H and Joshi HC: Reversal of P-glycoprotein-mediated multidrug resistance in cancer cells by the c-Jun NH2-terminal kinase. Cancer Res 66: 445-452, 2006

27. He D, Zhao XQ, Chen XG, et al: BIRB796, the inhibitor of p38 mitogen-activated protein kinase, enhances the efficacy of chemotherapeutic agents in ABCB1 overexpression cells. PLoS One 8: e54181, 2013. 